\title{
Analytic signal, depth and multispectral interpretation of areas within the Continental Terminal, North-western Nigeria
}

\author{
${ }^{* 1}$ AISABOKHAE, J; ${ }^{1}$ ADAMU, A; ${ }^{2}$ ORESAJO, B \\ ${ }^{1}$ Department of Applied Geophysics, ${ }^{2}$ Department of Geology, Federal University Birnin Kebbi, Nigeria \\ *Corresponding author email: joseph.aisabokhae@fubk.edu.ng
}

\begin{abstract}
This study utilized the ability of remote sensing and aeromagnetic data of the Continental Terminal, Northwestern Nigeria, to accentuate structural and lithological geologic features as well as depth estimation and mineral potential for exploitation purposes. The analytic signal and source parameter imaging filtering techniques on the magnetic data helped to identify causative magnetic bodies and space-depth relationship, two important indices in regional and ore body modelling. Depth interpretation result ranged from $120 \mathrm{~m}$ to $2000 \mathrm{~m}$ in the entire regolith cover where the basement rocks are overlain by clastic materials. Areas of deeper depths coincided well with regions of higher magnetic anomalies while areas of shallow depth coincided well with regions of lower magnetic anomalies with magnetic values ranging from $33121 \mathrm{nT}$ to $32980 \mathrm{nT}$ suggestive of a likelihood of having the magnetic unit of the basement at the top of the basement surface. The study identified the structural trend from the aeromagnetic map, showing a perfect agreement with the geologic map and Landsat- 8 imagery. The Landsat- 8 data was used for structural and lithological mapping and in general geological interpretation. Single band combination of 764 representing Red, Green and Blue were processed from the false colour composite image and pan-sharpened using the pan chromatic band to enhance structural features on the map. The study area showed no promise of hydrocarbon accumulation from the structural interpretation for economic benefits. However, economic-grade minerals were inferred due to magnetic anomalies that suggested accumulation of magnetic materials located within the proximity of lineaments.
\end{abstract}

\section{DOI: https://dx.doi.org/10.4314/jasem.v22i5.9}

Copyright: Copyright (C) 2018 Aisabokhae et al. This is an open access article distributed under the Creative Commons Attribution License (CCL), which permits unrestricted use, distribution, and reproduction in any medium, provided the original work is properly cited.

Dates: Received: 07 March 2018; Revised: 08 April: 2018; Accepted: 17 April 2018

Keywords: Continental terminal, Landsat-8, analytic signal, hydrocarbon accumulation

The term 'Continental Terminal' was first proposed by Killian (1931) for Saharan continental sediments of Miocene-Paleocene age. The terminology is now correctly used all over West and Central Africa as a stratigraphic unit covering sediments which are of continental origin of post-Eocene and pre-Quaternary age (Kogbe, 1979). The 'Continental Terminal' is largely represented in the Iullemmeden Basin by the Gwandu Formation with the type area in the Gwandu Emirate of North-western Nigeria. Magnetic prospecting is a geophysical method based on the examination of magnetic field anomalies of the earth caused by varying magnetization intensity of rocks (Gunn et al., 1997). Physical and geological prerequisites of this method implementation are based on the magnetic dissimilarities of rocks which form geological structures in the earth crust. The magnetic field of the earth magnetizes a rock to a variable degree which is determined by their magnetic susceptibility, intensity and magnetization force. Aeromagnetic investigation images the geomagnetic field variation which results from the changes in the percentage of magnetic materials in the rock. It surveys the variation in the distribution and type of magnetic minerals such as magnetite and pyrrhotite in the subsurface. These magnetic minerals can be mapped from the surface to greater depth in sedimentary terrains depending on the dimension, shape and the magnetic properties of the underlying rock (Emmanuel et al., 2011). The contact edges and depth of causative anomalies are important tools in providing information that forms a guide for subsequent exploration processes such as ore body modelling and drilling (Fairhead et al., 2006). The total field magnetic (TFM) data (figure 3) mapped in geophysical exploration helps to identify important targets for further investigation and processing. Proper reduction and filtering techniques such as analytic signal and depth extraction filters are applied to TFM data in this study and interpreted.The depth to basement, faults in the basement surface and the relief of the basement surface have direct relevance to the depositional and structural history of an area, and can best be studied using geophysical prospecting methods which have regional-scale investigative capacity (Graham et al., 2014).

The use of satellite imagery is now a standard technique in geoscience for mineral exploration, structural investigation and hydrogeology (Crosta et al., 2009). The most common structures, lineaments of

*Corresponding author email: joseph.aisabokhae@fubk.edu.ng 
diverse nature, drainage pattern and deductions regarding stress in the area are made. Landsat data are usually processed in several ways to accentuate the geological units and structure of the area. This particular combination of remotely sensed image data sets are employed to provide a unique selection of alternative options for evaluating which spectral products best indicate the geologic structures, rock types and surface materials (El Khidir, 2006). Airborne geophysical image processing is greatly facilitated by application of computer processing programs for digital outlook. The advantages of digital processing methods are their versatility, repeatability and the preservation of the original data precision (Graham et al., 2014). Digital data processing allows for correction of data for geometric and radiometric imperfections, improvement of visual quality of the image data, flexibility in enhancing or suppressing certain details vital for extraction, and colour-assisted mapping for accentuated interpretation. The objectives of this study are: (i) to estimate the depth to basement of the study area using aeromagnetic data; (ii) to interpret aeromagnetic data for structural trend and orientation of the basement rocks; (iii) to evaluate Landsat- 8 spectral bands for lithology mapping of the study area.

\section{MATERIALS AND METHODS}

Geological setting: The study area is located between longitude $4^{\circ} 30^{\prime \prime}$ and $5^{\circ} 30^{\prime \prime}$, and latitude $12^{\circ} 20^{\prime \prime}$ and $13^{\circ} 00^{\prime \prime}$. It is located about $28 \mathrm{~km}$ south west of Sokoto, Nigeria. The age indicated for the formation is early Eocene to Miocene. The climate is tropical, with high temperatures and rainfall for most of the year. Rainfall shows a marked seasonal variation with an average annual precipitation of $734 \mathrm{~mm}$. The rainfall is concentrated in a short wet season which extends from mid-May to mid-September whilst the dry season lasts for more than seven months; November to March/April with no single drop of rainfall. During the dry season, vegetative growth is stunted. The vegetation consists of mainly dicotyledonous plants, grasses and ferns. Daytime temperatures are very high (except during the harmattan) but as a result of transpiration, due to cloudless skies, the nights are very cold. During the harmattan, the wind coming from the desert is not only dry, but also dust laden, leading to impaired visibility due to haze of dust particles.

Stratigraphy of the Study Area: Theories of the origin of African interior basins have stressed the role of rifting (Cloos, 1939; Furon, 1963; Burke and Dewey, 1974). Rifts have been recognized in the Chad Basin and on the western flank of the Iullemmeden Basin by Radier (1959).

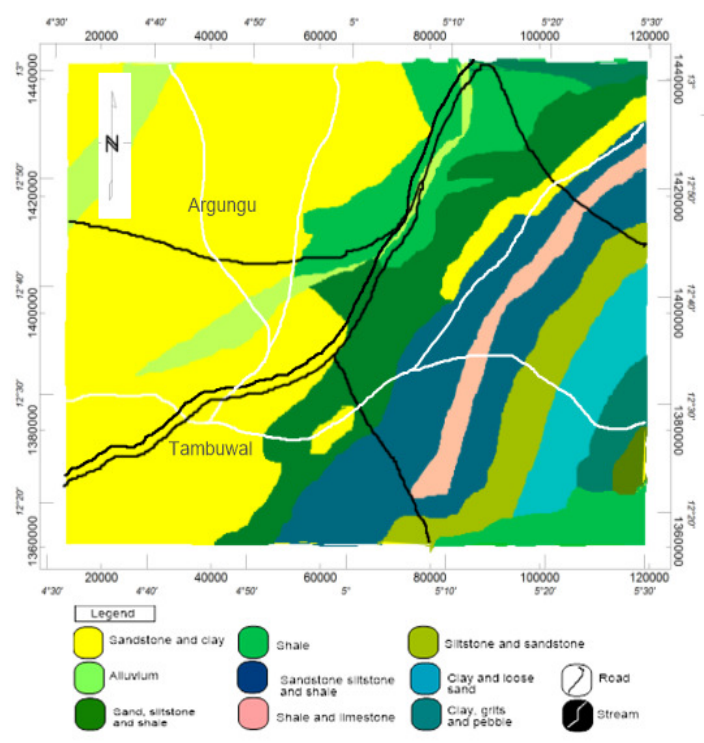

Fig 1, Geological map of the study area

More recent theories of cratonic subsidence and basin formation have emphasized the role of changes in mantle thermal regime, and subsidence due to flexure of the lithosphere in response to sediments and water load (Bott, 1976). Faure (1973) and Sloss and Spleed (1974) ascribed cratonic subsidence to sea floor spreading, plate tectonic and mantle thermal perturbations.

The migration of cratonic subsidence and marine sedimentation from Late Cenomanian in the Chad Basin to the Paleocene in the Iullemmeden Basin was attributed by Faure (1973) to horizontal relative translation between the lithosphere and the asthenosphere. According to Faure, crustal uplift occurs as continental lithosphere rides over bumps in the asthenosphere while subsidence occurs after the continental moves over the lithosphere bumps. Faure observed that the migration of cratonic subsidence from the Chad Basin to the Iullemmeden was at the rate of 1 to $2 \mathrm{~cm} / y e a r$. The rate and direction of migration was comparable with seafloor spreading and the motion of African plate. The Iullemmeden Basin occupies a broad depression between the Ahaagar Mountains and the Upper Guinea basement arch, and extends from northern Nigeria into the western Niger Republic and eastern Mali. South of Adrar des Iforas, the basin forms a narrow pan handle being located in the Goa graben. Apart from the Goa graben, no other rifts are known in the Iullemmeden Basin thus suggesting maximum subsidence of the basin during that time. The southeastern and western parts of the 
Iullemmeden basin suggesting maximum subsidence of the Iullemmeden Basin is located in Northwestern Nigeria which is stratigraphically representative of the exposed basin margin (Kogbe, 1979). The part of the Iullemmeden Basin in Northwestern Nigeria is called the Sokoto Sector (figure 2). It consists predominantly of a gently undulating plain with an average elevation varying from 250 to $400 \mathrm{~m}$ above sea level (Kogbe, 1979). The sediments of the Iullemmeden Basin were accumulated during four main phases of deposition. Overlying the Precambrian Basement unconformably, the Illo and Gundumi Formations, made up of grits and clay constitute the Pre-Maastrichtian "Continental Intercalaire" of West Africa. They are overlain unconformably by the Maastrichtian Rima Group, consisting of mudstones and friable sandstones (Taloka and Wurno Formations), separated by the fossiliferous, shelly Dukamaje Formation. The Dango and Gamba Formations separated by the calcareous Kalambaina Formation constitute the Paleocene Sokoto group (Kogbe, 1979). The overlying continental Gwandu Formation forms the postPaleocene Continental Terminal. The fourth phase in the depositional history of the sediments of the Sokoto sector of the Iullemmeden Basin took place during the Eocene when the Gwandu Formation of the Continental Terminal was deposited. Throughout the sedimentary basin of Northwestern

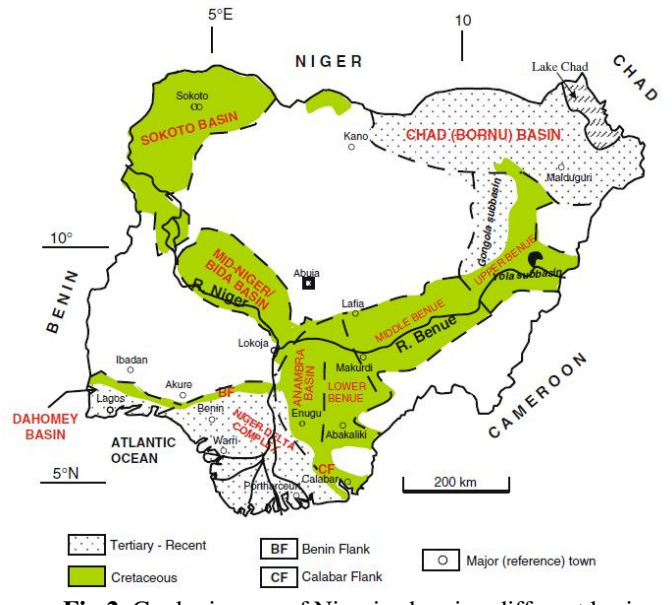

Fig 2, Geologic map of Nigeria showing different basin components (Emmanuel et al., 2011)

Nigeria, the Tertiary marine sediments of the Sokoto group are overlain disconformably by a thick series of deposits consisting predominantly of red and mottled massive clays, with sand intercalations. These sediments belong to the Gwandu Formation. It contains a number of prominent ridges and group of flat-topped, steep-sided hills capped by ironstone. The non-marine origin of Gwandu Formation is certain, and the sediments can be correctly attributed to a continental environment, or more precisely, to a lacustrine environment. The sands at the surface are near red in colour, often showing a colour banding and poor stratification. The mudstones often show a nodular structure with nodules suggestive of local turbulence in the depositional environment (Kogbe, 1979). Kaolinite clay dominates in the Gwandu Formation (figure 1). The dominance of this clay reveals the oxidising acid depositional environment of the Gwandu Formation and a rich characteristic of continental deposits. The prominence of this mineral in the Gwandu Formation sediments also confirm the presence of a not-distant source rock of micas and feldspars being weathered under hot and humid climate and degrading prolong transport.

Data Presentation: The aeromagnetic data is that of total field and is in a gridded form as a total magnetic intensity (TMI) map (figure 3). The magnetic data was processed in personal computer using Surfer 11 and Geosoft Oasis Montaj software. The Landsat-8 Level 1 standard terrain corrected images with image quality of 9 were processed using the Environment for Visualizing Images (ENVI) version 4.8 software (ITT, 2007) and the Environment Systems Research Institute (ESRI) ArcGIS version 10.1 software (ITT, 2007). The materials used for this study were aeromagnetic map of the study area, Landsat- 8 scene and geologic map of Nigeria. The aeromagnetic data was obtained from the Nigerian Geological Survey Agency (NGSA). The new high-resolution airborne survey carried out for NGSA by Furgo Airborne Services in 2004 used for this study was flown at 500m line spacing, altitude of $80 \mathrm{~m}$ and terrain clearance of $75 \mathrm{~m}$. The geomagnetic gradient was removed from the data using the International Geomagnetic Reference Field (IGRF) and the data was collected in digitized format. The geological data were digitized and georeferenced using WGS 84 Datum, UTM $31^{\circ} \mathrm{N}$ in order to use in the GIS software. A Landsat-8 OLI/TIRS scene (Path 191 Row 052) dated $11^{\text {th }}$ November $(0.01 \%$ cloud cover) was acquired for the year 2017 from the US Geological Survey archive.The empirical estimation approach for correction of the Landsat data utilized only the image data to remove atmospheric effects. It corrected for atmospheric path radiance which is at-sensor radiance contributed by atmospheric scattering. The data was converted to the Top-of Atmosphere (TOA) reflectance using radiometric coefficients (USGS, 2015b), where DN are converted to reflectance representing the ratio of the radiation reflected off a surface to the radiation striking it (Han and Nelson, 2015). The following equation was used to convert $\mathrm{DN}$ values to TOA reflectance: 


$$
\rho \chi=\frac{M_{\rho} X Q_{c a l}+A_{\rho}}{\sin \theta} .
$$

Where; $\rho \chi=$ Top-of-Atmosphere planetary reflectance (unitless); $\quad M_{\rho}=$ Reflectance multiplicative scaling factor of the band; $Q_{\text {cal }}=$ Level 1 pixel value in $\mathrm{DN} ; A_{\rho}=$ Reflective additive scaling factor of the band; $\Theta=$ Solar elevation angle.

Analytic Signal Filtering: The analytic signal can be applied in frequency or space domain, thereby generating a maximum directly over discrete bodies as well as their edges. Its amplitude is independent of magnetization direction. The simplification of magnetic data involves creating a function which is independent of body magnetization direction and ambient geomagnetic parameters. The analytic signal filter possesses this property and has been used for edge detection and depth estimation of magnetic bodies recently. The ability of the filter to generate a maximum value directly over the causative body and depth estimation makes it a desirable technique for magnetic data interpretation (Ansari and Alamdar, 2009). The amplitude A of the analytic signal of the total magnetic field is calculated from the three orthogonal derivative of the field, being defined as the square root of the squared sum of the vertical and horizontal derivatives of the magnetic field (Roset $e t$ al., 1992).

$|A(x, y)|=\sqrt{\left(\frac{\delta f}{\delta x}\right)^{2}+\left(\frac{\delta f}{\delta y}\right)^{2}+\left(\frac{\delta f}{\delta z}\right)^{2}}$

$A(x, y)$ is the amplitude of the analytical signal at (x, $\mathrm{y})$, and $F$ is the observed magnetic field at $(\mathrm{x}, \mathrm{y})$.

Although the analytic signal is a derivative product which enhances magnetic fabric, apart from its above attributes, it has a mapping shortcoming in that twodimensional features often tend to break up into bull's eyes anomalies, and strike continuity is lost. However, the advantage of this magnetic data enhancement method is that its amplitude function is always positive and does not need any assumption of the direction of the body magnetization (Jeng et al., 2003).

Source Parameter Imaging: The source parameter imaging (SPI) is a technique that uses an extension of the complex analytic signal to estimate magnetic depths. The estimate of the depths is independent of the magnetic inclination, declination, dip and strike and remnant magnetisation. The SPI accuracy has shown to be $+/-20 \%$ in tests on real data sets with drill hole control $(\mathrm{Li}, 2006)$. This accuracy is similar to that of Euler deconvolution, however, SPI has the advantage of producing a more complete set of coherent solution points and is easier to use. The source parameter imaging technique is represented mathematically (MacLeod et al., 1993) as;

$$
\text { Depth }=\frac{1}{K_{\max }}=\frac{1}{3.20 \sqrt{\left(\frac{\partial T \text { Tilt }}{\partial x}\right)^{2}+\left(\frac{\partial T i l t}{\partial y}\right)_{\max }^{2}}} \ldots \ldots \text {...(iii) }
$$

Where Tilt is given as Tilt $=\arctan \left(\frac{\partial T / \partial z}{H G R A D}\right)$, where HGRAD is the horizontal gradient, $\mathrm{T}$ is the total magnetic intensity, $\mathrm{K}$ is the wave number and $\frac{\partial T}{\partial x}$, $\frac{\partial T}{\partial y}, \frac{\partial T}{\partial z}$ are derivatives of $\mathrm{T}$ with respect to $\mathrm{x}, \mathrm{y}, \mathrm{z}$.

The SPI method calculates source parameters for gridded magnetic data. The method assumes either a 2D slopping contact or a 2D dipping thin-sheet model and is based on the complex analytic signal.

Multispectral Processing: Landsat imagery is composed by gray scale images corresponding to spectral bands. When a composite of three bands (red, green, and blue) is created a colourful multispectral image will result, which can be true colour or false colour (in this case, a NIR band is used instead of blue band). There are different band combination possibilities to enhance relevant features for lithological mapping or mineral exploration.

\section{RESULTS AND DISCUSSION}

The basement is an assemblage of rocks that underlie a sedimentary basin (Gunn et al., 1997). If it contains numerous magnetic rock units, these can provide information of the morphology of the sedimentary basin and its structure. If the magnetic units in the basement occur at the basement surface, the depth determination for these will map the basin floor morphology. The analytic signal derivative image (fig 4) highlights the variation in the distribution of magnetic sources in the study area. Discontinuities and anomaly texture are also accentuated. The analytic signal map displayed high intensity throughout the entire stretch of the west, and upper and lower portions of the extreme east, while regions with low magnetic intensities extend unconventionally from north to south in the middle of the map.

Three major magnetic zones have been delineated. The high magnetic anomaly zone inscribed $\boldsymbol{A} \boldsymbol{X}$ are the migmatite rocks (Telford et al., 1990) which are found throughout the latitudinal stretch in the western axis of the map. The low magnetic anomaly zone $(\boldsymbol{B Y})$ believed to be dominated by sedimentary rocks including limestone and dolomite was alienated by a sharp magnetic contrast represented by a white continuous line to highlight lithological contrast. The 
undulating anomaly zone labelled $\boldsymbol{C Z}$ is believed to be a zone of altered basement rocks of likely igneous origin comprising of granite and basalt with isolated anomalies taped in with broken white lines.

Isolated magnetic anomalies, generally circular or oval in plan and several hundred meters across may arise from accumulations of magnetite and/or pyrrhotite which may be associated with economic-grade mineral deposits (Gunn et al., 1997). Such deposits which precipitate from mineral-bearing solutions are frequently located within or adjacent to major faults.

The false colour composite image which is the surface reflectance image as a result of atmospheric correction applied was transformed by reapplying the RGB into 764 to enhance the structural features of the map. The data was further pan sharpened using the panchromatic band 8 to reduce the cell size to $15 \mathrm{~m}$ and to clearly demarcate geological boundaries. The Landsat- 8 image confirmed the lithological and geologic trend of the top soil sediments overlying the basement rock investigation generated by the aeromagnetic data.

Band 7 (SWIR: 2.11-2.29 $\mu \mathrm{m}$ ) coincides with absorption band caused by hydrous minerals (clay, mica, some oxides, and sulfates) making them appear darker. It is usually used in lithological mapping. Band 6 (SWIR: 1.57-1.65 $\mu \mathrm{m}$ ) accentuates soil and rock discrimination. It is sensitive to moisture variation in vegetation and soils and more so, sensitive to presence of ferric iron or hematite rocks. Band 4 (Visible: 0.64$0.67 \mu \mathrm{m}$ ) is an effective band for discrimination of soil from vegetation. This band is good for discriminating soil and vegetation and delineating soil cover.

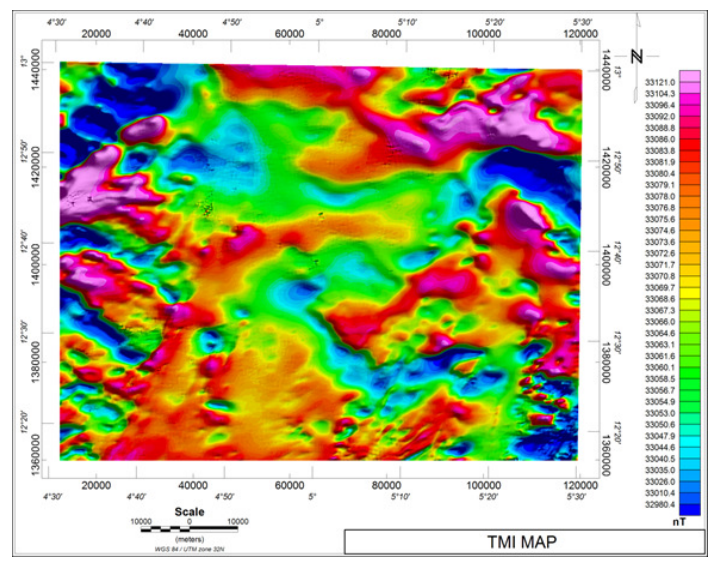

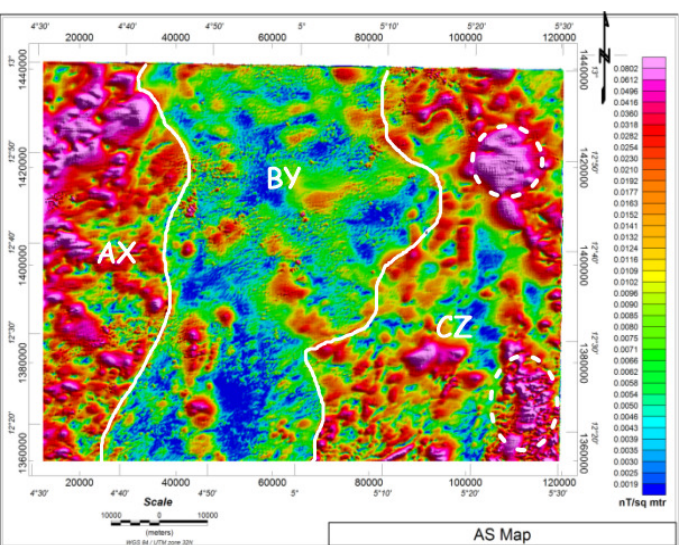

Fig 4, Analytical signal map of the study area

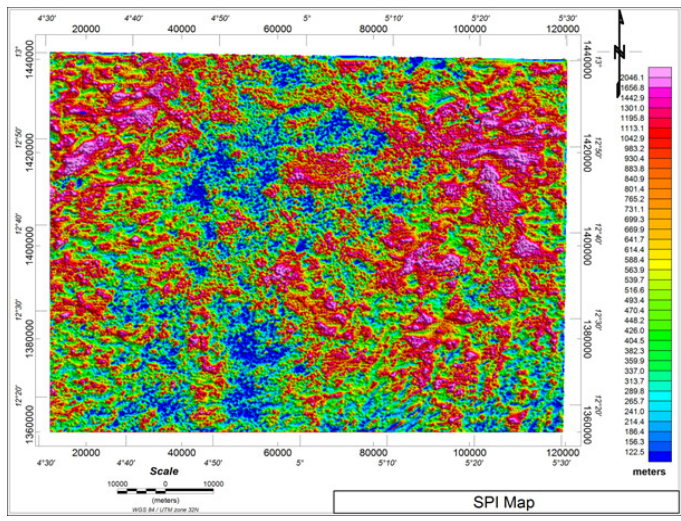

Fig 5, Source parameter imaging of the study area

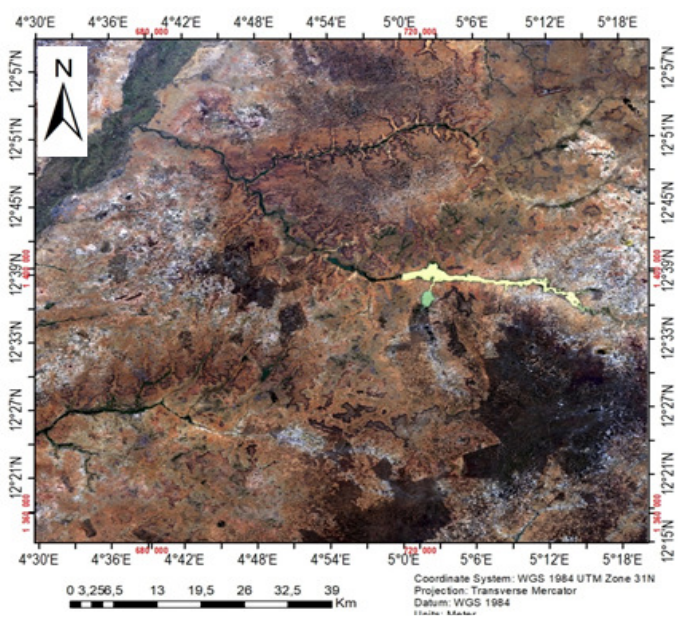

Fig 6, False colour composite map of the study area

Fig 3, Total intensity map of the study area 


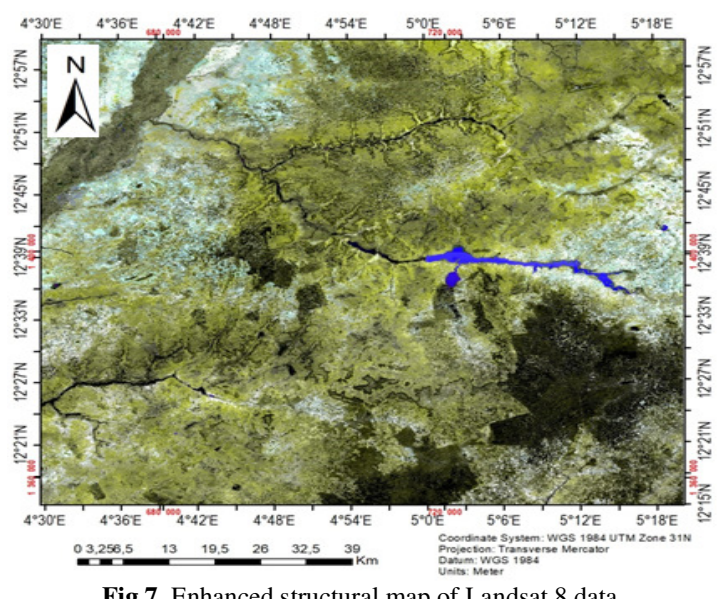

Fig 7, Enhanced structural map of Landsat 8 data

The lithological map created (figure 7) based on Landsat- 8 imagery analysis proved to be effective in basic lithological mapping that can be useful in regional study or in investigation of an unknown area. Basically, clays, conglomerates and metasediments are the constituents of the studied area and the blue portion on the image depicts water body. The published geological maps show a varying consistency of metasedimentary bodies trending from NE to SW in this region. Also, some contacts showed on published maps can be identified on Landsat- 8 imagery. The structural orientation interpreted from the magnetic map (figure 4) and the Landsat-8 image (figure 7) reveal trend direction of $\mathrm{NE}-\mathrm{SW}$. The $\mathrm{NE}-\mathrm{SW}$ trend is broad and dorminant in the study area and thus reflect the trend of the youngest and most recent tectonic occurrence. Depth interpretation result as seen in figure 5 in this study ranges from $120 \mathrm{~m}$ to $2000 \mathrm{~m}$ in the entire regolith cover where the basement rocks are overlain by clastic materials. Areas of deeper depths coincide well with regions of higher magnetic anomalies while areas of shallow depth coincide well with regions of lower magnetic anomalies suggestive of a likelihood of having the magnetic unit of the basement at the top of the basement surface. From the economic point of view, the study area has a low potential for hydrocarbon accumulation due to the shallow sediment thickness. The average sedimentary thickness of $679 \mathrm{~m}$ estimated from this study is unfavourable for hydrocarbon generation and accumulation. However, the area may be viable for mineral accumulation due to tectonic activities believed to have affected the area. The study area can be further investigated for economic mineral deposits - mainly ferruginous; construction raw materials laterites and ferruginous sandstones; hydrogeology sandstone aquifers; and industrial mineral deposits such as clay.
Conclusion: The purpose of this study was to conduct an integrated investigation using processed and enhanced aeromagnetic and Landsat- 8 data sets to map lithological units, geologic structures and estimate depths in the Continental Terminal and environs. Filtering techniques of aeromagnetic method included first order vertical and horizontal derivatives, analytic signal and finally, source parameter imaging. Also, remote sensing techniques were helpful in authenticating the lithological mapping of the area in tandem with the aeromagnetic data. The trend of deposition correlates perfectly between both data sets thus proving the ability of such integrated approach in mapping lithological units in regional scale.

Acknowledgement: A deep and profound appreciation goes to Dr. Natasha Stanton of the Department of Oceanography, Rio D'Janeiro State University, Brazil, for her assistance and guidance during the set-up of this research.

\section{REFERENCES}

Ansari, A; Alamdar, K (2009). Reduction to the pole of Magnetic Anomalies using analytic signal. Wrld Appld Sci. J. 7(4): 405 - 409.

Bedell, R; Crosta, A (2009). Basic image processing. Rev.in Econ. Geol. 16: 237-256.

Bott, M (1976). Mechanism of Basin Subsidence - An introductory review. Tectonophys. 36, $1-4$

Burke, K; Dewey, J (1974). Two plates in Africa during the Cretaceous - Nature 249: 313 - 315

Cloos, H (1939). Hebung - Spaltung - Vulcanismus. Ged. Rdsch. 30: 405 - 527

Cooper, G; Cowan, D (2006). Enhancing potential field data using filters based on the local phase. Compt. and Geosci. 32: 1586-1591.

Cooper, G; Cowan, D (2008). Edge enhancement of potential filed data using normalized statistics. Geophy. 73 (3): H1-H4.

Crosta, A; De Souza Filho, C (2009). Mineral exploration with Landsat Thematic Mapper (TM) / Enhanced Thematic Mapper plus (ETM+): A review of fundamentals, characteristics, data processing, and case studies. Rev.in Econ. Geol. 16: 59-82

El Khidir, S (2006). Remote Sensing and GIS Applications in Geological Mapping, prospecting for minerals deposits and groundwater Berber Sheet Area, Northern Sudan. (Ph. D. Thesis). Al Neelain University, Khartoum, Sudan. 
Emmanuel, K; Ajana, G; Augustine, I; Leonard, M (2011). Interpretation of the aeromagnetic anomalies over Maiduguri-Dikwa depression, Chad Basin, Nigeria. Archiv. of Appld Sci. Research. 3(4): 499508

Environment Systems Research Institute (ESRI). ArcGIS 10.1; ESRI: Redlands, CA, USA, 2005.

Fairhead, JD; Williams, SE (2006). Evaluating normalized magnetic derivatives for structural mapping. SEG2006 New Orleans Extended Abstract.

Faure, H (1973). Vertical movements and horizontal translation of the lithosphere. In: Runcorn, S; Tarling, O (Ed) Implication of Continental drift to the earth sciences. Vol.2. Academy Press. $731-733$.

Furon, R (1963). Geology of Africa - Oliver and Boyd

Graham, K; Preko, DD; Boamah, D (2014). Geological and Structural Interpretation of part of the Buem Formation, Ghana using Aerogeophysical Data: J. of Enviromnt and Earth Sci. 4(4): 17-31.

Green, A; Berman, M; Switzer, P; Craig, M; (1988). A transformation for ordering multispectral data in terms of image quality with implications for noise removal: IEEE Transactions on Geoscience and Remote Sensing. 26(1): 65-74

Gunn, P.J. and Dentith, M.C (1997). Magnetic responses associated with mineral deposits. ASGO J. of Australian Geol. and Geophy. 17(2): 145-158.

Han, T; Nelson, J (2015). Mapping hydrothermally altered rocks with Landsat- 8 imagery: A case study in the KSM and Snow field zones, northwestern British Columbia. In: Geological Fieldwork 2014, British Columbia Ministry of Energy and Mines, British Columbia Geological Survey Paper Vol. 1, 103-112.

ITT Visual Information Solutions. Environment for Visualising Images (ENVI) 5.1; ITT Visual Information solution. Boulder, CO, USA, 2007

Jeng, Y; Lee, YL; Lin, MJ (2003). Integrated signal enhancements in magnetic investigation in archaeology. J. of Appld. Geophy. 53 : 31 - 48.

Kilian, CM (1931) Des principaux complexes continentaux du Sahara. CR Soc. Geol. France. 5: p109
Kogbe, C (1979). Geology of the south eastern sector of the Iullemmeden Basin. Bulletin of Geol. Departmnt. ABU Zaria. (2)1: 44-63.

Li, X (2006). Understanding 3-D analytic signal amplitude. Geophy. 71(2): L13-L16.

MacLeod, IN; Jones, K; Dai, TI (1993). 3-D analytic signal in the interpretation of total magnetic field data at low magnetic latitudes. Expl. Geophy. 24: 679-687.

Odeyemi, IB (1981). A review of orogenic events in the Precambrian basement of Nigeria, West Africa. Geologische Rundschau. (70)3. 897-909

Radier, H (1959). Contribution a l'etude geologique du Soudan oriental (A.O.F) le basin cretace at tertiare de Gao le Detroit Soudanais. Bull Serv. Geol. Prosp. Min. 26: 315 - 556

Roset, WR; Verheof, J; Pilkington, M (1992). Magnetic interpretation using the 3D analytic signal, Geophy. 57(6): $116-125$

Sploos, LL (1972). Synchrony of Phanerozoic sedimentary - tectonic event of the North American craton and the Russian platform. 24 ${ }^{\text {th }}$ Intl. Geol. Congr. Montreal. Sect.6. $24-32$

Sploos, LL; Speed, RC (1974). Relationship of cratonic and continental margin tectonic episodes. In: Dickinsen, E. (Ed): Tectonics and sedimentation. Spec. Publ. Soc. Econ. Paleont. Min. 22: 98 -119

Telford, WM; Geldart, R; Sheriff, A (1990). Applied Geophysics: Cambridge University Press, Cambridge. p792.

USGS (2015a). Landsat 8 (L8) Data Users Handbook. Version 1.0. p105.

USGS (2015b). Using the USGS Landsat-8 Product: http://landsat.usgs.gov/Landsat8_Using_Product.ph p. Accessed Aug., 2015

USGS (2015c). Frequently Asked Questions about the Landsat Missions: http://landsat.usgs.gov//L8_band_combos.php. Accessed Aug., 2015

Vanhellemont, P; Ruddick (2013). Landsat-8: Science and product vision for terrestrial global change research. Rem. Sens. of Environ. 145: 154-172.

Verduzco, B; Fairhead, JD; MacKnenzie, C (2004). New insights into magnetic derivatives for structural mapping. The Leading Edge. 19: 116-119. 